\title{
Developmental regulation of the bcl-2 family during spermatogenesis: Insights into the sterility of bcl-w-I- male mice
}

\author{
T Meehan ${ }^{1}, \mathrm{KL}_{\text {Loveland }}{ }^{\star, 1} \mathrm{D}$ de Kretser ${ }^{1}, \mathrm{~S} \mathrm{Cory}^{2}$ and \\ CG Print ${ }^{2,3}$ \\ ${ }^{1}$ Monash Institute of Reproduction and Development, Monash University, \\ Melbourne, Victoria 3168, Australia \\ 2 The Walter and Eliza Hall Institute of Medical Research, PO Royal Melbourne \\ Hospital, Victoria 3050, Australia \\ ${ }^{3}$ Current address: Department of Pathology, Cambridge University, Cambridge \\ UK \\ * Corresponding author: KL Loveland, Monash Institute of Reproduction and \\ Development, Monash Medical Centre, 246 Clayton Road, Clayton, Victoria \\ 3168, Australia, Tel: 613 9594-7125; Fax: 613 9594-7111; \\ E-mail: kate.loveland@med.monash.edu.au
}

Received 15.5.00; revised 15.9.00; accepted 18.10.00

Edited by DR Green

\begin{abstract}
Expression of $b c l-w$, a close relative of $b c l-2$ is essential for male fertility in mice. Although the initial wave of spermatogenesis in bcl-w $-I$ - mice proceeds normally until $3-4$ weeks of age, adults fail to produce sperm. To clarify why bcl-w is essential for adult but not juvenile spermatogenesis, we investigated the expression pattern of eight bcl-2 family members. We found that both the level and pattern of expression varied in different cell types during juvenile and adult spermatogenesis. Anti-apoptotic genes bcl-w, bcl-2 and $b c l-x_{L}$ were all expressed in spermatogonia during juvenile spermatogenesis, but only bcl-w was detected in spermatogonia of adult mice. A similar shift was evident in Sertoli cells. This developmental regulation may co-ordinate physiological germ cell apoptosis in wild type mice and account for the time of onset for pathological germ cell apoptosis in bcl-w - Ianimals. Cell Death and Differentiation (2001) 8, 225-233.
\end{abstract}

Keywords: $b c l-2$ family; testis; $b c l-w ; b c l-x_{L}$; bax; bak; bad; bim; apoptosis; spermatogonium; Sertoli cell

Abbreviations: wt, wild type; dpp, days post partum

\section{Introduction}

Apoptosis is essential for the removal of cells during many developmental processes, including spermatogenesis. ${ }^{1,2}$ Proteins of the $\mathrm{Bcl}-2$ family are key regulators of apoptosis (reviewed in ${ }^{3}$ and ${ }^{4}$ ): certain members promote cell survival (e.g. Bcl-2, Bcl- $\mathrm{x}_{\mathrm{L}}, \mathrm{Bcl}-\mathrm{w}$ and $\mathrm{A} 1 / \mathrm{Bfl}-1$ ) while others promote cell death (e.g. Bax, Bak, Bad and Bim), and their relative abundance in any cell may determine its fate. ${ }^{4}$
Mammalian spermatogenesis is activated soon after birth. In mice, during the first 5 days post partum, mitotically arrested gonocytes within the testicular cords re-enter the cell cycle, differentiate into spermatogonia and proliferate. At approximately day 10 , spermatogonia start to differentiate into spermatocytes, and initiate meiosis. By day 20 , haploid spermatids are evident and by day $35,{ }^{5}$ spermatozoa appear in the lumen of seminiferous tubules. Subsequent waves of spermatogenesis in adult mice occur continuously, with self-renewing spermatogonial stem cells regularly re-seeding the germ cell population.

During the first spermatogenic wave, somatic cells in the testis are also proliferating and maturing. The Sertoli cells, which surround and support the germ cells, cease proliferation by day $16,{ }^{6}$ the fetal Leydig cell population, still present at birth, remains stable through adult life, while the adult type Leydig cell population emerges from a separate precursor pool first recognized at day $10^{7}$ and, by around day 25 , the contractile peritubular myoid cells surrounding the seminiferous cords adopt their mature, flattened phenotype and secrete the basal lamina components characteristic of the mature testis. ${ }^{8}$

The first wave of spermatogenesis is accompanied by extensive apoptosis of pre-meiotic germ cells, which may reflect adjustment in the number of germ cells to match the capacity of the available supporting Sertoli cells. ${ }^{9,10}$ While germ cell apoptosis also occurs during adult spermatogenesis, it is less common, and may in some cases represent selective removal of damaged cells. ${ }^{11-13}$

Spermatogenic defects observed in genetically modified mice suggest that several $b c l-2$ family members play critical roles in the maintenance of testicular homeostasis. Inactivation of endogenous pro-apoptotic bax, or transgenic expression of anti-apoptotic $b c l-2$ or $b c /-x_{L}$ in germ cells resulted in the accumulation of pre-meiotic cells and a failure of both the first spermatogenic wave and adult spermatogenesis. ${ }^{14-16}$ In contrast, in mice lacking a functional $b c l-w$ gene, the first wave of spermatogenesis progressed normally, but the increased rate of germ cell degeneration initiated between 2 and 4 weeks after birth resulted in adult sterility. ${ }^{17,18}$

While several $\mathrm{Bcl}-2$ homologs have been detected in the testis, their distribution profiles within the various cell types has not been addressed in detail. In this study, we have investigated the mRNA expression pattern of three antiapoptotic family members $b c /-2$ and its closest homologs, $b c l-x_{L}$, and $b c l-w$. Four pro-apoptotic relatives were also surveyed: bax and bak, which are quite similar in structure to bcl-2, bad and bim, which are related only by the small $\mathrm{BH} 3$ domain. ${ }^{3}$ The data suggest that different combinations of apoptosis regulators contribute to homeostasis of each cell type within the seminiferous epithelium at various 
stages of testicular development. The implications of these results for the testicular phenotype of mice lacking expression of $b c l-w$ or having perturbed expression of other $b c l-2$ family members are discussed.

\section{Results}

\section{Developmental expression Bcl-w protein in the testis}

Previous studies relying on lacZ expression ${ }^{17}$ and in situ RNA hybridization ${ }^{18}$ have differed about which testicular germ cells express $b c l-w$, and, in particular, about whether spermatogonia do. To clarify this issue, we immunostained sections of adult testes with a new rat anti-Bcl-w monoclonal antibody, $16 \mathrm{H} 12 .{ }^{19}$ The $\mathrm{Bcl}-\mathrm{w}$ protein was detected in both type $\mathrm{A}$ and intermediate spermatogonia, and also in a subset of Sertoli cells (Figure 1A). The specificity of the antibody was confirmed by the absence of any staining in testis sections from a $b c /-w-I-$ mouse (Figure $1 \mathrm{~B}$ ), and the specificity of the staining technique was confirmed using an isotype-matched negative control antibody on normal testis (Figure 1C).

We estimated the level of $\mathrm{Bcl}-\mathrm{w}$ protein at various stages of testicular development by performing immunoblots on lysates of testis from 5-day-old mice through to adulthood using a monoclonal antibody $13 \mathrm{F9}$ (Figure 1). The $21 \mathrm{kDa}$ $\mathrm{Bcl}-\mathrm{w}$ protein was evident in day 5 testis, which contains spermatogonia as the most mature germ cell type present. The concentration of bcl-w protein in testis increased until day 16 , thereafter remaining relatively constant into adulthood. As expected, no $\mathrm{Bcl}-\mathrm{w}$ protein was recognized in the testis of adult $b c /-w-/-$ mice, confirming the specificity of the antibody for immunoblotting. The signal detected in the testis of adult Hsp70-2-I- mice, which contain no round or elongated spermatids, ${ }^{20}$ was similar to that observed in the wild-type sample. This finding is consistent with our previous in situ RNA hybridization analysis ${ }^{18}$ in which the mRNA signal was predominant in spermatogonia and Sertoli cells and absent from elongating spermatids (see also Figure 3). These data are consistent with the presence of $\mathrm{Bcl}-\mathrm{w}$ mRNA in mitotic spermatogonia, as is now accepted by MacGregor et al. ${ }^{21}$ They are also consistent with the recent immunohistochemical analysis of Yan et al. ${ }^{24}$

\section{Several bcl-2 family members are expressed in the testis}

A ribonuclease protection assay was used to determine which other $b c /-2$ family members were expressed in adult testis, and to quantify their relative expression levels during development (Figure 2A). Transcripts were evident throughout postnatal development and in the adult for each of the three pro-apoptotic family members tested (bak, bax and bad), and for two of the anti-apoptotic members ( $b c l-w, b c l-x_{L}$; Figure 2A). However, bcl-2 RNA was not detected in the adult, and A1 RNA was not detected at any age. Quantitation and normalization of each sample using a 'housekeeping' gene, L32 (Figure 2B), indicated that the level of bcl-w mRNA declined, but not significantly, somewhere between 3-4 weeks post partum, while levels of bax and bak remained constant. A dramatic and significant increase in both $b c l-x_{L}$ and bad RNAs occurred between 1 and 3 weeks, and levels stayed relatively high in the adult. The changes in expression levels may be due to the shift in the relative proportions of each cell type that occurs during this interval, as progressively

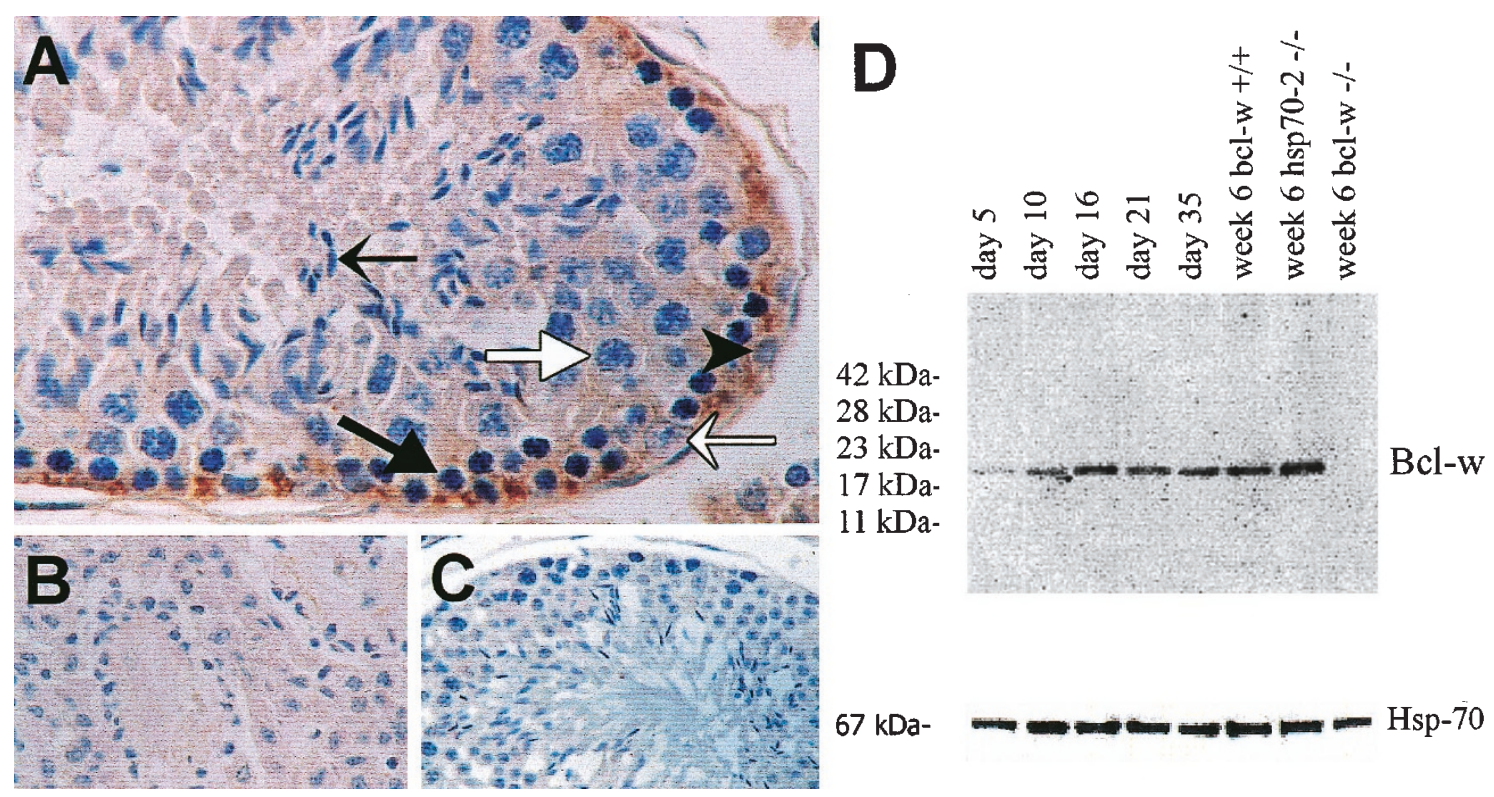

Figure $1 \mathrm{Bcl}-\mathrm{w}$ protein expression in testis. Immunostaining of adult testis sections from $(\mathbf{A})$ wild type (wt) and (B) bcl-w-I- mice with rat anti-Bcl-w monoclonal antibody $16 \mathrm{H} 12$ and immunostaining of $(\mathbf{C})$ wt testis with isotype control antibody (300-fold magnification). Black arrowhead indicates spermatogonia; thick black arrow, leptotene and zygotene spermatocytes; thin white arrrow, pachytene spermatocytes; thin black arrow, elongating spermatids; white arrowhead, Sertoli cell. (D) Lysates from testis of wt mice aged $5,10,16,21,35$ days post partum and 6 week-old wt, bcl-w-I- and $H s p 70-2-/-$, mice were examined using a rat antiBcl-w monoclonal antibody $13 \mathrm{F9}$ (upper panel) and, as a loading control, mouse anti-Hsp-70 monoclonal antibody N6 (lower panel) 

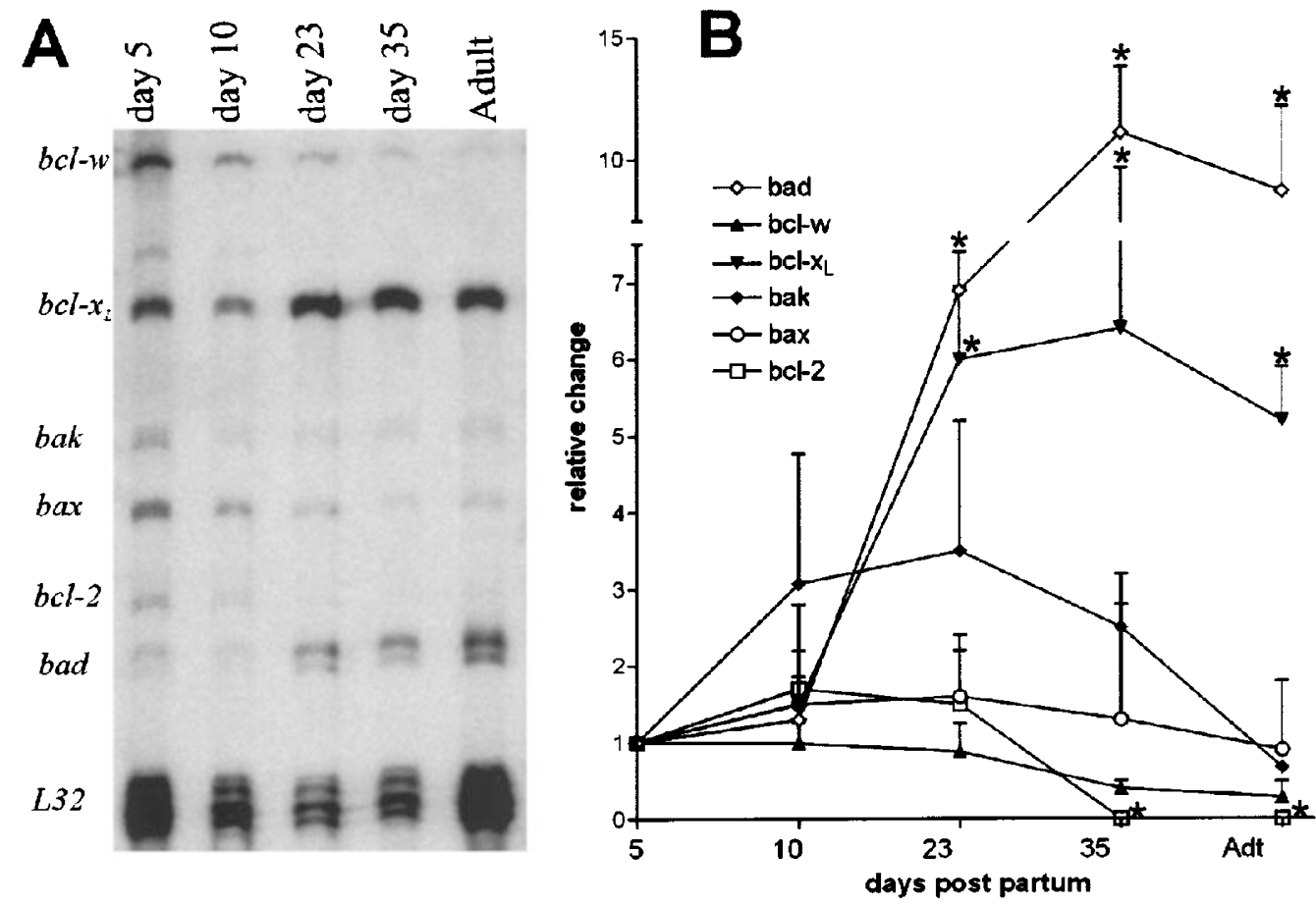

Figure 2 Expression of $\mathrm{Bcl}-2$ family members in mouse testis during development. Ribonuclease protection analysis using ${ }^{32} \mathrm{P}$-labeled anti-sense riboprobes for the indicated $b c /-2$ homologues (see Materials and Methods) in testes from days 5, 10, 23, 35 and young adult wild type mice. $L 32$ and GAPDH riboprobes provided loading controls. (A) Representative autoradiograph. (B) Quantification of hybridization data using phosphoimage analysis. Data represent the mean densitometric value obtained for each RNA \pm S.D. in four experiments, normalized to the L32 value within each sample. Significant differences $(P<0.05)$ are indicated by asterisks. A1 was detected using control target RNA supplied by manufacturer, but was absent from all testis samples

more mature germ cell types first emerge. Alternatively, or in addition, this numerical change could reflect a change in the expression levels within a particular cell type.

\section{Cellular localization of transcripts in the adult testis}

In situ RNA hybridization was performed to determine which cell types in the adult testis expressed the various bcl-2related RNAs. For each experiment, the specificity of the antisense riboprobe was confirmed using a complementary sense riboprobe and, in the case of the $b c l-w$ probe, hybridization to sections from the $b c l-w-/-$ mouse testis (data not shown).

Three distinct localization patterns were observed in the germ cells (Figure 3). While the bcl-w and bax signals were most intense in spermatogonia, the $b c l-x_{L}$ and bad signals were greatest in pachytene spermatocytes and round spermatids. In contrast, bak and bim RNAs had a widespread distribution, with more intense signals evident in pachytene spermatocytes and round spermatids. No signal was obtained using the $b c l-2$ riboprobe on sections of adult testis, although bcl-2 RNA was readily apparent in immature testis samples examined simultaneously (see Figure 4).

Table 1 summarizes the results for each cell germ cell type and also for the somatic Sertoli cells: (i) Hybridization signals with $b c l-w$ and bax probes were highest in Type A and intermediate spermatogonia, slightly reduced in Type $B$ spermatogonia and early spermatocytes, and further reduced in pachytene spermatocytes, early round spermatids, Sertoli cells, and peritubular cells. No hybridization with either probe was detected in elongating spermatids or Leydig cells (Figure 3A,D); (ii) The $b c l-x_{L}$ and bad probes showed little to no hybridization to spermatogonia, or to preleptotene, leptotene or zygotene spermatocytes, but gave intense signals in pachytene spermatocytes and round spermatids. No hybridization to elongating spermatids, Sertoli cells, peritubular cells or Leydig cells was observed (Figure 3B,F); (iii) The bak and bim riboprobes hybridized to all spermatogonial types, all spermatocyte types and both round and elongating spermatids. The most prominent signals for each were in pachytene spermatocytes and round spermatids. The bim probe also hybridized to all elongating spermatids (Figure $3 \mathrm{E}, \mathrm{H}$ ) whereas bak was clearly evident in spermatids up to step 9, levels were low in step 10-12 spermatids, and undetectable at steps 1316. The bim mRNA signal was distinct in Sertoli cells, while the bak signal was faint. Both bak and bim were detected in peritubular cells, but neither probe appeared to bind to Leydig cells.

\section{Expression of bcl-2 family members during the first spermatogenic wave}

The expression pattern of each $b c /-2$ family member during the first wave of spermatogenesis was then assessed by performing in situ hybridization on testis sections from 10- and 

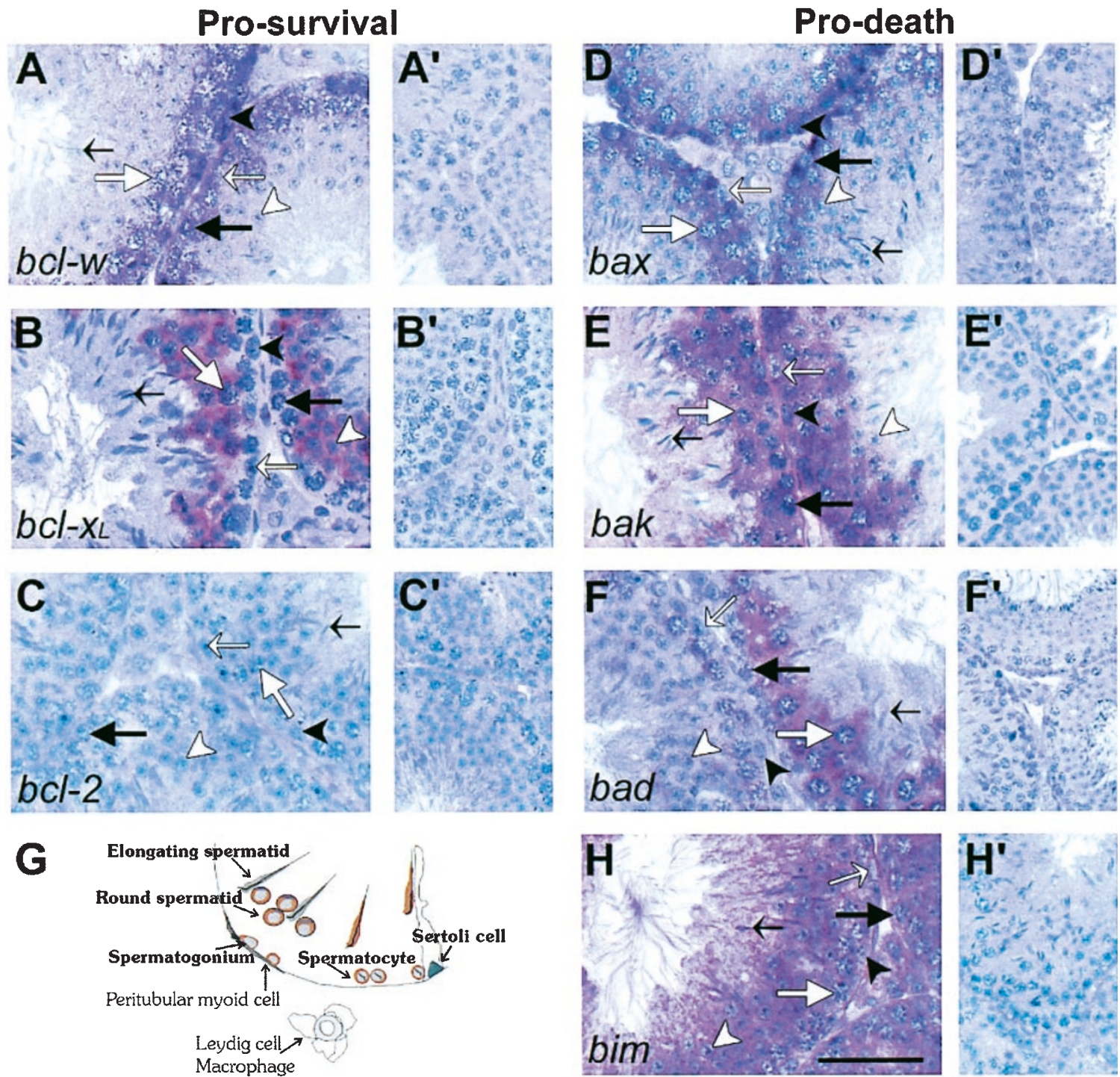

Figure $3 \mathrm{Bcl}-2$ family expression in the adult mouse testis. Testis sections were hybridized with antisense $(\mathbf{A}, \mathbf{B}, \mathbf{C}, \mathbf{D}, \mathbf{E}, \mathbf{F}$ and $\mathbf{G})$ or sense $\left(\mathbf{A}^{\prime}\right.$, etc.) riboprobes for transcripts of the following genes: $b c l-w(\mathbf{A}) ; b c l-x_{L}(\mathbf{B}) ; b c l-2(\mathbf{C}) ; b a x(\mathbf{D}) ; b a k(\mathbf{E}) ; b a d(\mathbf{F})$ and $b i m(\mathbf{H})$ (see Materials and Methods). G illustrates the various cell types present in the testis. Scale bar represent $50 \mu \mathrm{m}$. Thin white arrow indicates Sertoli cells; black arrowhead, spermatogonia; thick black arrow, leptotene and zygotene spermatocytes; thick white arrow, pachytene spermatocytes; white arrow head, round spermatids and thin black arrow, elongating spermatids

23-day old mice. These ages correspond to time points when spermatogonia and spermatocytes, respectively, represent the most predominant mature germ cell types present. The results revealed significant changes during development. In particular, $b c l-x_{L}$ and bad hybridization to spermatogonia was high at 10 days, but undetectable by 23 days (Figures 4 and 5 ; Table 1).

10 days post partum The $b c l-w, b c l-x_{L}, b c l-2$, bax, bak, bad and bim probes gave prominent hybridization signals in spermatogonia, and weaker but clearly discernible signals in Sertoli cells. Only bcl-2, bak and bim trancripts were detected in the fetal Leydig cells.

23 days post partum Prominent hybridization with the $b c l-w$, $b c l-2$ and bax probes was observed in spermatogonia and spermatocytes. In contrast, the $b c l-x_{L}$ and $b a d$ probes did not label spermatogonia weakly if at all, but gave strong signals in pachytene spermatocytes and round spermatids. The bim and bak probes showed hybridization to spermatogonia, spermatocytes and round spermatids, the most intense signal being observed in spermatogonia. Weak to moderate signals were observed in Sertoli cells with the bcl-w, bcl-2, bax, bak, bad and bim probes, and in Leydig cells with the bcl-2, bak and bim probes.

\section{Discussion}

Mammalian spermatogenesis is a remarkable developmental process, requiring exquisite balance between germ cell proliferation, differentiation and apoptosis. A variety of genetic studies have suggested that the $b c l-2$ family plays 

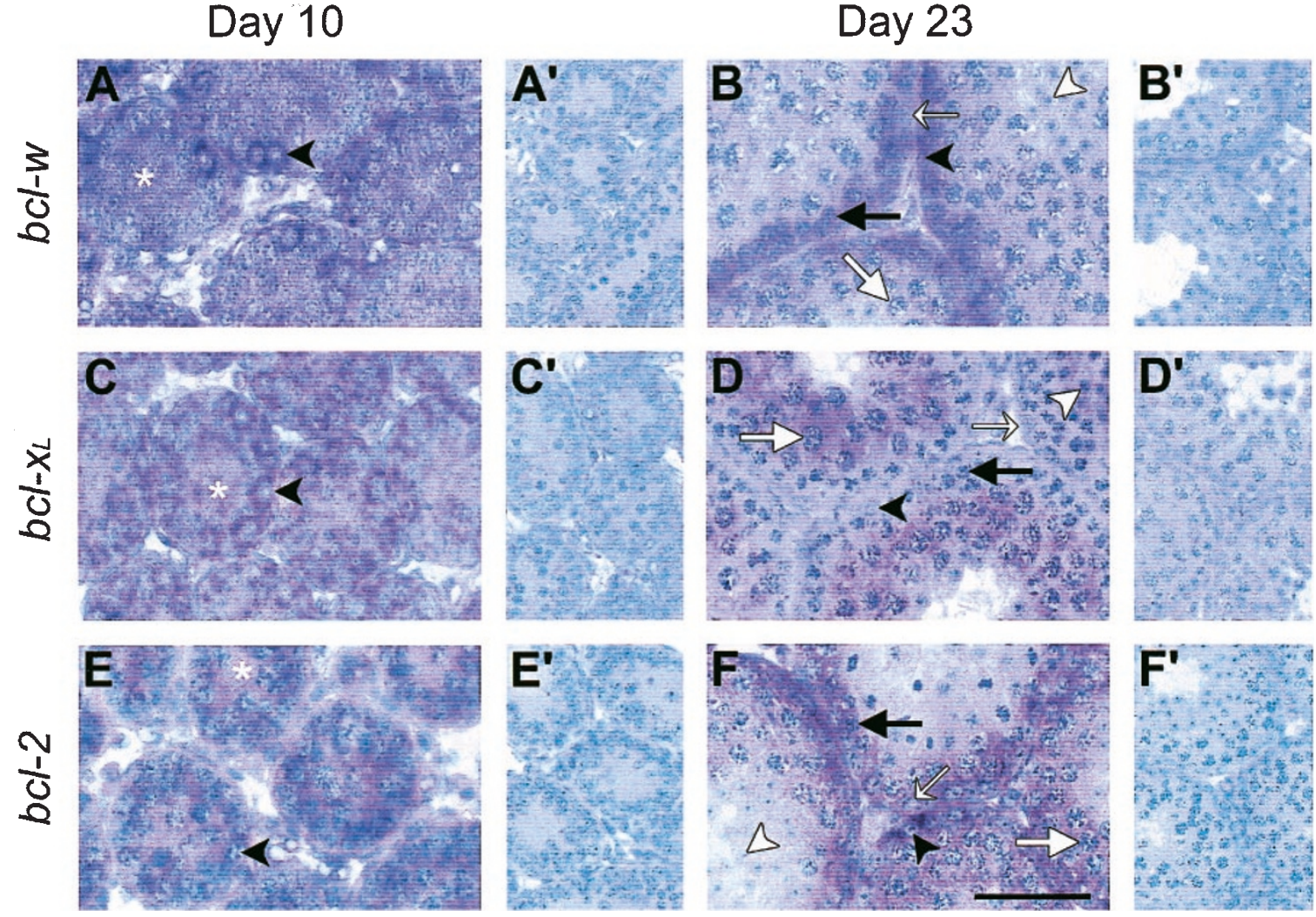

Figure 4 Expression of anti-apoptotic members of the $B c /-2$ family during the first wave of spermatogenesis. Testis sections from days 10 and 23 , mice were hybridized with antisense (A, B, C, D, E and F) or sense ( $\mathbf{A}^{\prime}$ etc.) probes for $b c l-w, b c l-x_{L}$ and $b c l-2$, as for Figure 3 . Bcl-w was detected in spermatogonia at day 10 (A) and in spermatogonia and early spermatocytes at day $23(\mathbf{B})$. Bcl- $x_{L}$ was detected in spermatogonia at day 10 (C) and in spermatocytes and round spermatids at day $23(\mathbf{D})$. Bcl-2 was detected in spermatogonia at day $10(\mathbf{E})$ and spermatogonia and spermatocytes at day $23(\mathbf{F})$. Sertoli cell cytoplasm stained with all probes at day 10 , and with $b c /-w$ and $b c l-2$ at day 23 . Scale bar represents $50 \mu \mathrm{m}$. Asterisk or thin white arrow indicates Sertoli cells; black arrowhead, spermatogonia; thick black arrow, leptotene and zygotene spermatocytes; thick white arrow, pachytene spermatocytes; and white arrowhead, round spermatids

key roles in integrating the diverse positive and negative signals impacting on the resident stem cells and their differentiating progeny. To determine which members influence the fate of each cell type in the testis at different developmental stages, we have investigated the expression patterns of four anti-apoptotic family members $\left(b c l-2, b c l-x_{L}\right.$, $b c l-w$ and $A 1)$ and four pro-apoptotic family members (bax, bak, bad and bim). Other than bcl-w, we chose to localize the mRNAs that encode bcl-2 family proteins rather than the proteins themselves, since a complete set of specific antibodies was not available for immunohistochemical analysis.

Our localization of these mRNAs in adult mouse testis is generally in good agreement with previous reports of their corresponding proteins. The predominant localization of $b c l-w$ mRNA to spermatogonia and Sertoli cells matches our detection of the bcl-w protein by immunohistochemistry and Western blot, and this result is in accordance with other recent work. ${ }^{24}$ To date there is no direct evidence that the relatively low $\mathrm{bcl}-\mathrm{w}$ signal observed in spermatocytes and spermatids is translated. The lack of a detectable bcl-w in situ hybridization signal in Leydig cells is similar to that illustrated by Yan et al. ${ }^{24}$
As described here and in other studies, ${ }^{14,16,25,26} \mathrm{bcl}-2$ cannot be detected in the adult testis, while in another report, bcl-2 levels were observed to rise dramatically after irradiation. ${ }^{27}$ The $b c l-x_{L}$ protein has been localized to spermatocytes and spermatids in the adult testis, ${ }^{27,28}$ in agreement with our mRNA localization data. The proapoptotic Bim protein appears to be restricted to elongating spermatids and Sertoli cells, ${ }^{29}$ while Bim mRNA appears more widely distributed. Our in situ hybridization data support a widespread expression pattern for bak and bax in the adult rodent testis, including Sertoli cells, spermatogonia and spermatocytes, as described using immunohistochemistry and Western blot. ${ }^{24}$ In general, the few discrepancies between the mRNA and protein localization may be attributed to using methods with different sensitivities and specificities, but the possibility that mRNAs are made but not translated must also be considered. ${ }^{30}$

Sperm production initiates from the self-renewing population of immature spermatogonia, whose continued survival is therfore of paramount importance. Spermatoginia were found to express several pro-apoptosis bcl-2 homologs during puberty and in the adult. Expression of 
Table 1 Expression of $b c l-2$ family in cells of the developing and mature testis

\begin{tabular}{|c|c|c|c|c|c|c|}
\hline & \multicolumn{3}{|c|}{ Anti-apoptotic } & \multicolumn{3}{|c|}{ Pro-apoptotic } \\
\hline & Day 10 & Day 23 & Adult & Day 10 & Day 23 & Adult \\
\hline $\begin{array}{l}\text { Mitotic spermatogonia } \\
\quad(A, \text { Int, B) }\end{array}$ & $\begin{array}{l}\text { bcl-w+ } \\
\text { bcl- } \mathbf{x}_{\mathrm{L}+} \\
\text { bcl-2+ }\end{array}$ & $\begin{array}{l}\text { bcl-w+ } \\
\text { bcl- } x_{\mathrm{L}}- \\
\text { bcl-2+ }\end{array}$ & $\begin{array}{l}\text { bcl-w+ } \\
\text { bcl-x } x_{L}- \\
\text { bcl-2- }\end{array}$ & $\begin{array}{l}\text { bax+ } \\
\text { bak+ } \\
\text { bad+ } \\
\text { bim+ }\end{array}$ & $\begin{array}{l}\text { bax+ } \\
\text { bak+ } \\
\text { bad- } \\
\text { bim+ }\end{array}$ & $\begin{array}{l}\text { bax+ } \\
\text { bak+ } \\
\text { bad- } \\
\text { bim+ }\end{array}$ \\
\hline $\begin{array}{l}\text { Meiotic early spermatocytes } \\
\text { (Prelep, Lep and Zyg) }\end{array}$ & & $\begin{array}{l}\text { bcl-w+ } \\
\text { bcl-x }- \\
\text { bcl-2+ }\end{array}$ & $\begin{array}{l}\text { bcl-w+ } \\
\text { bcl-x }{ }_{L}- \\
\text { bcl-2- }\end{array}$ & & $\begin{array}{l}\text { bax+ } \\
\text { bak+ } \\
\text { bad- } \\
\text { bim+ }\end{array}$ & $\begin{array}{l}\text { bax+ } \\
\text { bak+ } \\
\text { bad- } \\
\text { bim+ }\end{array}$ \\
\hline $\begin{array}{l}\text { Meiotic late spermatocytes } \\
\text { (Pachy) }\end{array}$ & & $\begin{array}{l}\text { bcl-w } \pm \\
\text { bcl- } x_{L}+ \\
\text { bcl-2+ }\end{array}$ & $\begin{array}{l}\text { bcl-w+ } \\
\text { bcl-x } x_{L}^{+} \\
\text {bcl-2- }\end{array}$ & & $\begin{array}{l}\text { bax- } \\
\text { bak- } \\
\text { bad+ } \\
\text { bim+ }\end{array}$ & $\begin{array}{l}\text { bax+ } \\
\text { bak+ } \\
\text { bad+ } \\
\text { BIM+ }\end{array}$ \\
\hline Round spermatids & & $\begin{array}{l}\text { bcl-w- } \\
\text { bcl- } x_{L}+ \\
\text { bcl-2 } \pm\end{array}$ & $\begin{array}{l}\text { bcl-w } \pm \\
\text { bcl- } x_{L}+ \\
\text { bcl-2- }\end{array}$ & & $\begin{array}{l}\text { bax- } \\
\text { bak+ } \\
\text { bad+ } \\
\text { bim+ }\end{array}$ & $\begin{array}{l}\text { bax- } \\
\text { bak+ } \\
\text { bad+ } \\
\text { bim+ }\end{array}$ \\
\hline Elongating spermatids & & & $\begin{array}{l}\text { bcl-w- } \\
\text { bcl- } x_{L}- \\
\text { bcl-2- }\end{array}$ & & & $\begin{array}{l}\text { bax- } \\
\text { bak+ } \\
\text { bad- } \\
\text { bim+ }\end{array}$ \\
\hline Sertoli cells & $\begin{array}{l}\text { bcl-w+ } \\
\text { bcl- } \mathbf{x}_{\mathrm{L}+} \\
\text { bcl-2+ }\end{array}$ & $\begin{array}{l}\text { bcl-w } \pm \\
\text { bcl-x } \\
\text { bcl-2+ }\end{array}$ & $\begin{array}{l}\text { bcl-w+ } \\
\text { bcl-x }{ }_{\mathrm{L}}- \\
\text { bcl-2- }\end{array}$ & $\begin{array}{l}\text { bax+ } \\
\text { bak+ } \\
\text { bad+ } \\
\text { bim+ }\end{array}$ & $\begin{array}{l}\text { bax } \pm \\
\text { bak+ } \\
\text { bad- } \\
\text { bim+ }\end{array}$ & $\begin{array}{l}\text { bax } \pm \\
\text { bak+ } \\
\text { bad- } \\
\text { bim+ }\end{array}$ \\
\hline
\end{tabular}

In day 10 testis, the germ cell population is comprised exclusively of spermatogonia, which include type A (A), intermediate (Int) and Type B (B) spermatogonia. The most abundant germ cell types at day 23 are the spermatocytes, which include preleptotene (Prelep), leptotene (Lep), zygotene (Zyg) and pachytene (Pachy) spermatocytes, and the more mature round spermatids are starting to appear. In the adult testis, all germ cell types are present, including elongating spermatids. Bold text highlights major developmental changes in expression patterns detected by in situ hybridization. Only bim transcripts were detectable in Leydig cells. + indicates readily detectable hybridization signal, \pm indicates faint signal and - indicates no signal.

the counter-balancing anti-apoptosis homologs in this population, however, became progressively restricted during development (Table 1). At the earliest stage sampled (day 10), $b c /-w, b c l-x_{L}$ and $b c l-2$ transripts were readily detected. By day 23 , however, $b c /-x_{L}$ was no longer detectable in spermatogonia, although spermatocytes and round spermatids were positive. By maturity, the pattern had again changed, bcl-2 expression having become undetectable. A peak in the incidence of spermatogonial and preleptotene spermatocyte apoptosis has been observed between days $13-21$ in the mouse ${ }^{31}$ and this period of germ cell apoptosis may coincide with the progressive restriction in expression of anti-apoptotic bcl-2 homologs.

Concordant with the change in spermatogonial expression of bcl-2 family members, Sertoli cells also undergo development changes. Between days 10 and 23, bcl- $x_{L}$ and bad mRNAs are lost from Sertoli cells, while bcl-2 is lost after day 23 but prior to completion of the first wave of spermatogenesis. This may affect the overall balance of pro- and anti-apoptotic members within these supporting cells, rendering them susceptible to apoptotic stimuli. Thus the absence of bcl-w may impact directly on Sertoli cell survival, leading to structural lesions within the seminiferous epithelium. At this time, the cell type 'most affected' or 'first affected' by bcl-w depletion is unknown, and resolution of this will require the use of conditional knockouts or germ cell transplantation studies.

Of the four pro-survival homologues screened, only $b c l-w$ appears to be expressed in spermatogonia and Sertoli cells in adult mice. Although other known prosurvival family members $\left(\mathrm{Mcl}-1\right.$, Diva/Boo) ${ }^{32-34}$ remain to be screened, the failure of adult spermatogenesis in $b c l-w-l-$ mice demonstrates that $b c l-w$ is crucial for sustained spermatogenesis in the adult. Expression of other pro-survival homologues $\left(b c /-x_{L}\right.$ and $\left.b c l-2\right)$ at earlier stages of development presumably accounts for the apparently normal course of pre-pubertal spermatogenesis in $b c /-w-/-$ mice.

In mice lacking Bax, pre-meiotic germ cells accumulate abnormally during the first wave of spermatogenesis, but they subsequently degenerate and normal adult spermatogenesis is never established. ${ }^{14}$ Interestingly, a similar phenotype results from over-expression of $b c /-2$ or $b c /-x_{L}$ in spermatogonia via transgenesis. ${ }^{15,16}$ In each of these mutants, the ratio of pro-survival to pro-death proteins is increased, rescuing many pre-meiotic germ cells that would normally be destined to die. Why then, does spermatogenesis abort? The most likely explanation is that each Sertoli cell can support the differentiation of only a limited number of germ cells ${ }^{10}$ and the nurturing function fails when the germ cell : Sertoli cell ratio is too high. Even after the first 
Day 10
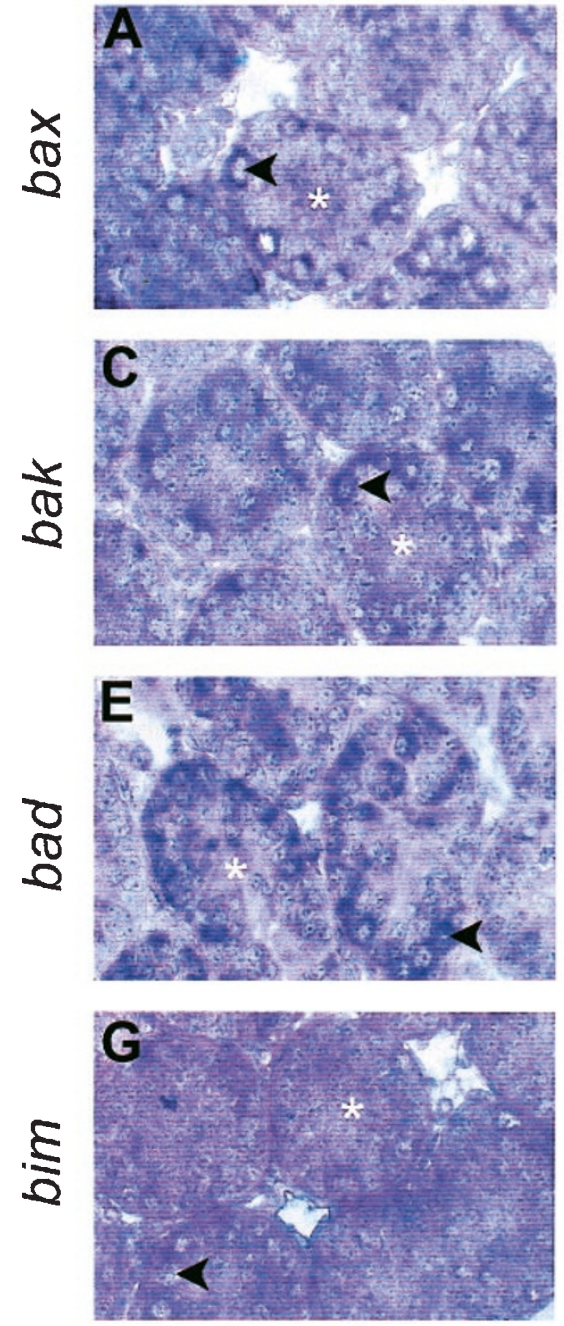

Day 23
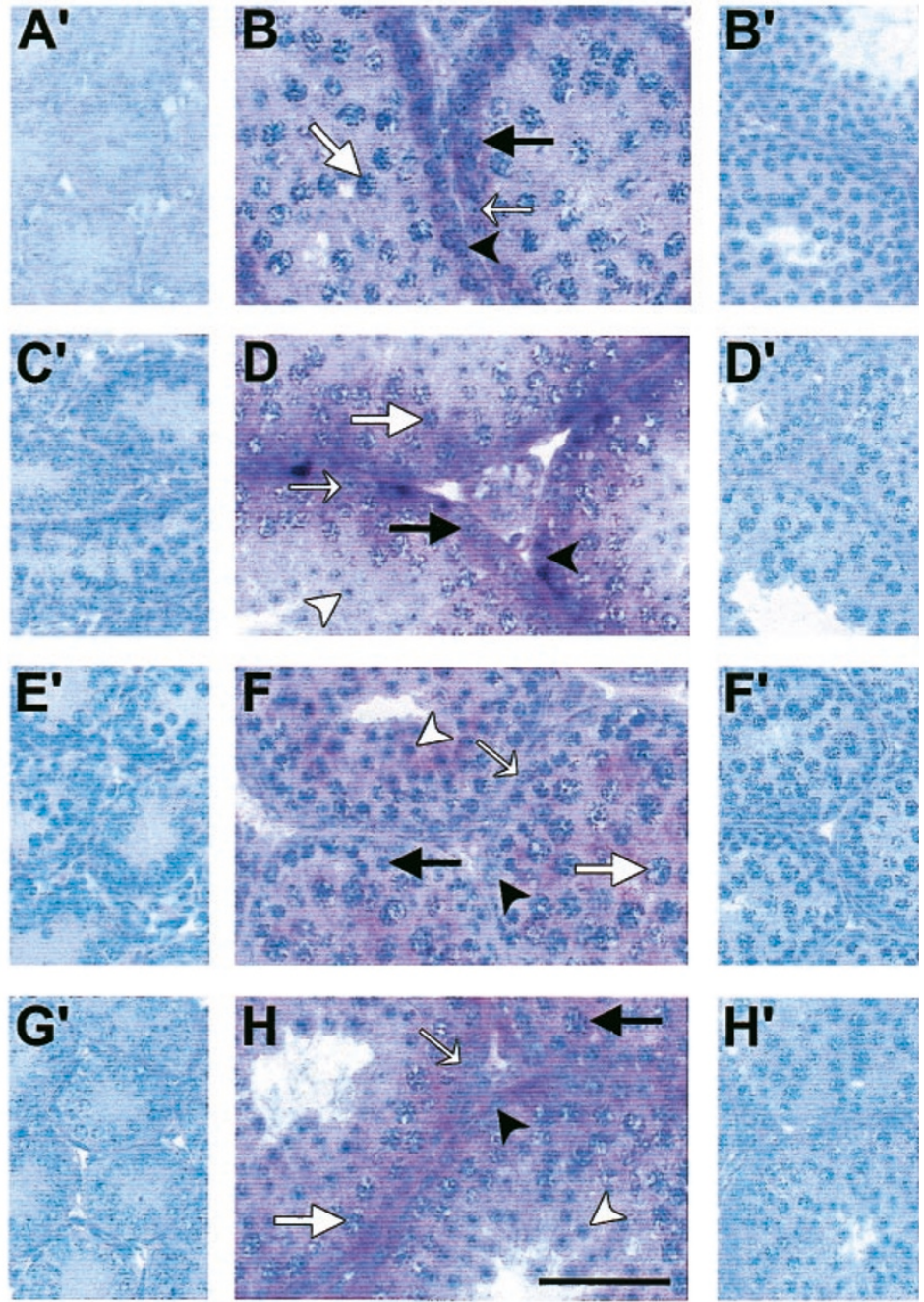

Figure 5 Expression of pro-apoptotic members of the $\mathrm{Bcl}-2$ family during the first wave of spermatogenesis. In situ hybridization with bax, bad and bim antisense (A, B, C, D, E. F, G and H) or sense ( $\mathbf{A}^{\prime}$, etc) riboprobes was performed as for Figure 4. Bax was detected in spermatogonia at day 10 (A) and in spermatogonia and early spermatocytes at day 23 (B). Bak was detected in spermatogonia at day 10 (C) and in spermatogonia and spermatocytes at day 23 (D). Bad was detected in spermatogonia at day $10(\mathbf{E})$ and late spermatocytes and round spermatids at day $23(\mathbf{F})$. Bim was detected in spermatogonia at day $10(\mathbf{G})$ and in spermatogonia through to round spermatids at day $23(\mathrm{H})$. Sertoli cells staining was detected using all probes, but only the bim probe gave a clear signal in Leydig cells. Scale bar represents $50 \mu \mathrm{m}$. Asterisk and thin white arrow indicates Sertoli cells; black arrowhead, spermatogonia; black arrow, leptotene and zygotene spermatocytes; white arrow, pachytene spermatocytes; and white arrowhead, round spermatids

cohort of excess cells was eliminated, the continuous overproduction of germ cells would persist in genetically modified animals, creating a sustained challenge to the integrity of the seminiferous epithelium. Whether the effect is primarily on Sertoli or germ cell function, or both, is unclear.

A complex set of coordinated interactions of hormones and cytokines is required to establish and sustain normal spermatogenesis. ${ }^{35}$ In cultures of immature testis cells, $\operatorname{TGF} \beta 1$ and $\beta 2$ increase apoptosis in gonocytes, ${ }^{36}$ the quiescent germ cell population present at birth, while fibroblast growth factor-2, leukemia inhibitory factor, and ciliary neurotrophic factor enhance gonocyte surivival. ${ }^{37,38}$ In several studies of adult spermatogenesis, stem cell factor and follicle stimulating hormone were observed to reduce apoptosis in mitotic and meiotic cells in vitro ${ }^{39}$ and in vivo. ${ }^{12,40}$ More specific knowledge about how hormones and cytokines regulate spermatogenesis through their impact on bcl-2 family member expression and function will greatly enhance our understanding of both normal and disrupted spermatogenesis. A role for $\mathrm{FSH}$-stimulated upregulation of stem cell factor in germ cell survival through upregulation of pro-survival bcl-2 family member synthesis is suggested by recent data using the adult rat. ${ }^{39}$ The importance of the Fas/FasL system in mediating the response of the testis to damage has also been described, ${ }^{41}$ and it will be informative to understand how these separate pathways for apoptosis regulation ${ }^{42}$ each contribute cellular homeostasis in the testis. 
In conclusion, we have demonstrated that a distinct shift in the pattern of expression of bcl-2 family members occurs within the seminiferous epithelium during testis development. This highlights the functional difference between the first wave of spermatogenesis and in the adult, differences that are characteristic of both germ cells and somatic cells. Our findings (this study and ${ }^{18}$ ) support the critical role of $b c l-w$ in the maintenance of spermatogenesis in the adult mouse. It will be important to determine whether this is also true in man and whether lesions in $b c /-w$ account for certain types of male sterility.

\section{Materials and Methods}

\section{Mice}

Mice were bred at the Walter and Eliza Hall Institute; $b c l-w-/$ - mice were back-crossed for at least six generations on to a $\mathrm{C} 57 \mathrm{BL} / 6 \mathrm{~J}$ background. All investigations conformed to the NHMRC/CSIRO/AAC Code of Practice for the Care and Use of Animals for Experimental Purposes and were approved by the Royal Melbourne Hospital Animal Ethics Committee.

\section{Immunohistochemistry}

Testes were fixed in Histochoice fixative (Amresco, OH, USA), paraffin embedded and $5 \mu \mathrm{M}$ sections cut on to glass slides. Following re-hydration, sections were incubated for $30 \mathrm{~min}$ sequentially in: $0.2 \mathrm{M}$ glycine $10 \% \quad(\mathrm{v} / \mathrm{v}) \quad \mathrm{H}_{2} \mathrm{O}_{2} / 10 \% \quad(\mathrm{v} / \mathrm{v})$ methanol, $0.2 \%$ Triton $\mathrm{X}-100$ and $0.5 \%$ blocking reagent (TSA, NEN Life Science Products Inc, Boston, USA). Sections were incubated overnight at $4^{\circ} \mathrm{C}$ with undiluted rat anti-Bcl-w monoclonal antibody, $16 \mathrm{H} 12$ culture supernatant (kindly provided by $\mathrm{Dr}$. L O'Reilly). ${ }^{19}$ This antibody detects endogenous Bcl-w protein in Western blots and immunoprecipitation. Primary antibody was detected with biotinylated anti-rat $\kappa$ antibody (Silenus, Melbourne, Australia) and the tyramide signal amplification system (TSA, NEN Life Science Products Inc, Boston) according to the manufacturer's instructions. Slides were then counterstained with haematoxylin.

\section{Western blot analysis}

Testes were removed, immediately frozen in isopentane on dry ice, and homogenized at $4{ }^{\circ} \mathrm{C}$ in buffer $(20 \mathrm{mM}$ Tris- $\mathrm{HCl} \mathrm{pH} 7.4,1 \mathrm{mM}$ EGTA, $135 \mathrm{mM} \mathrm{NaCl}_{2}, 1.5 \mathrm{mM} \mathrm{MgCl}_{2}, 10 \%$ glycerol and $1 \%$ Triton X$100)$ containing protease inhibitors ("Complete", Boehringer Mannheim, Mannheim, Germany). Lysates were centrifuged at $10000 \times g$ for $10 \mathrm{~min}$ and proteins $(10 \mu \mathrm{g})$ in the supernatant were resolved by SDS-PAGE (10-20\% acrylamide gel) and transferred to nitrocellulose membranes (Hybond-C extra, Amersham, UK). Following overnight incubation at $4{ }^{\circ} \mathrm{C}$ in blocking buffer $(5 \%$ dried skim milk powder, $1 \%$ casein, $0.05 \%$ Tween-20 in PBS), membranes were incubated for $1 \mathrm{~h}$ at room temperature with $1: 4$ dilution of rat anti-Bcl-w monoclonal antibody $13 \mathrm{Fg} .{ }^{19}$ Primary antibodies were detected with horseradish peroxidase-conjugated anti-rat antibody and chemiluminescent reagents (Amersham). As a control for loading and blotting, the membrane was re-probed with a 1:5000 dilution of anti-Hsp-70 monoclonal antibody N6 ascites (kind gift from Dr. Robyn Anderson, Peter MacCallum Cancer Institute), and the primary antibody detected as above. Testes from Hsp70-2 knockout mice were a kind gift from Dr E Mitch Eddy. ${ }^{20}$

\section{Ribonuclease protection analysis}

Ribonuclease protection analysis was performed using a commercially available probe (RiboQuant Multi-Probe mAPO-2, Pharmingen) according to the manufacturer's instructions. Briefly, a set of ${ }^{32} \mathrm{P}$ labeled antisense riboprobes specific to $b c l-2$ family members $\left(b c l-x_{L}\right.$, bcl-w, bad, bax, bak, $A 1$ and $b c l-2)$ and ubiquitously expressed controls ( $L 32$ and GAPDH) was hybridized in excess to total RNA $(10 \mu \mathrm{g})$ prepared by acid-phenol extraction. ${ }^{22}$ Single-stranded RNA was digested with RNAse A/RNAse T1 mix, and the RNAse-protected probes were resolved by denaturing polyacrylamide gel electrophoresis. Gels were dried, exposed to X-ray film (X-Omat; Eastman Kodak, Princeton, NJ, USA) and the signal collected for quantitation on a Molecular Dynamics Phosphoimage Analyser (FLA2000, Fujifilm, Japan). The signal obtained for the L32 internal loading standard was used to calculate the relative units of mRNA expression. For each testis age analyzed, RNA was prepared from two independent tissue pools. The probe set was labeled four separate times for analyses on samples from each testis age. Statistical significance between ages was determined by the One-Way Anova using Newman-Kewls Multiple Comparison Test. Significance was determined at the level $P<0.05$. Data is presented as mean \pm s.d., and graphs were produced using Graph Pad Prism Version 2.

\section{In situ hybridization}

Complementary sense and anti-sense digoxigenin-labeled ripoprobes were generated from linearized plasmid DNA termplates. ${ }^{23}$ All were verified by sequencing before use. Riboprobes corresponded to the following sequences: residues $118-410$ of mouse $b c l-w$ cDNA (GenBank U59746), residues $96-860$ of human $b c l-x_{L} c D N A$ (GenBank Z23115), residues 1-458 of mouse bax cDNA (GenBank L22472), residues 600-1091 of mouse bad cDNA (GenBank L37296), residues 75-700 of human bak cDNA (GenBank U23765), residues 31-755 of human bcl-2 cDNA (GenBank M14745) and residues 1591 of mouse bim cDNA (GenBank AF032459). Paraffin-embedded sections of Bouins fixed tissues were dried onto microscope slides and treated with 1-5 $\mu \mathrm{g} / \mathrm{mL}$ proteinase $\mathrm{K}$ (in $50 \mathrm{mM}$ EDTA, $100 \mathrm{mM}$ Tris$\mathrm{HCl} \mathrm{pH} \mathrm{8.0)} \mathrm{for} 30 \mathrm{~min}$ at $37^{\circ} \mathrm{C}$, hybridized to the riboprobes (100$200 \mathrm{ng} / \mathrm{ml}$ ) at 50 or $60^{\circ} \mathrm{C}$ for $16 \mathrm{~h}$, and washed to $0.1 \times \mathrm{SSC}$ at the hybridization temperature. ${ }^{22}$ The sections were exposed to an alkaline phosphatase-conjugated anti-digoxigenin antibody (Boehringer Mannheim, Germany), riboprobe binding was detected with the nitroblue tetrazolium chloride/bromo-chloro-indolyl phosphate substrate (Pierce One-Step; Rockford, IL, USA), and the slides were counterstained with haematoxylin and mounted under GVA (Zymed, USA) mount.

\section{Acknowledgments}

This work was supported by grants from NHMRC (Australia; Reg. Key 973002 and 973218), NIH, USA; (RO1 CA43540 to S Cory. CG Print was supported by fellowships from NHMRC and HRC (New Zealand). 


\section{References}

1. Print CG and Loveland KL (2000) Germ cell suicide: new insights into apoptosis during spermatogenesis. BioEssays 22: 423-430

2. Vaux DL and Korsmeyer SJ (1999) Cell death in development. Cell 96: 245-254

3. Adams JM and Cory S (1998) The Bcl-2 protein family: arbiters of cell survival. Science 281: $1322-1326$

4. Yang E and Korsmeyer SJ. (1996) Molecular thanatopsis: a discourse on the BCL2 family and cell death. Blood 88: $386-401$

5. McCarreyJR. Development of the germ cell. (1993) Celland MolecularBiologyo the Testis. Desjardins $C$ and Ewing LL, eds. New York: Oxford University Press Inc. pp. 58-89

6. Orth JM (1982) Proliferation of Sertoli cells in fetal and postnatal rats: a quantitative autoradiographic study. Anat. Rec. 203: 485-492

7. Mendis-Handagama SM, Risbridger GP and de Kretser DM (1987) Morphometric analysis of the components of the neonatal and adult rat testis interstitium. Int. J. Androl. 10: 525-534

8. Palombi F, Farini D, Salanoya M, deGrossi S and Stefanini M. (1992) Development and cytodifferentiation of peritubular myoid cells in the rat testis. Anat. Rec. 233: $32-40$

9. Allan DJ, Harmon BV and Kerr JFR (1987) Cell death in spermatogenesis In Perspectives on mammalian cell death. Potten CS, ed. (London: Oxford University Press) pp. 229-258

10. Orth JM, Gunsalus GL and Lamperti AA (1988) Evidence from Sertoli celldepleted rats indicates that spermatid number in adults depends on numbers of Sertoli cells produced during perinatal development. Endocrinology 122: 787 794

11. Burgoyne PS and Baker TG (1984) Meiotic pairing and gametogenic failure. Symp. Soc. Exp. Biol. 38: 349-362

12. Packer Al, Besmer $P$ and Bachvarova RF (1995) Kit ligand mediates survival of type A spermatogonia and dividing spermatocytes in postnatal mouse testes. Mol. Reprod. Dev. 42: 303-310

13. Odorisio T, Rodriguez TA, Evans EP, Clarke AR and Burgoyne PS. (1998) The meiotic checkpoint monitoring synapsis eliminates spermatocytes via p53independent apoptosis. Nature Genetics 18: 257-261

14. Knudson CM, Tung KS, Tourtellotte WG, Brown GA and Korsmeyer SJ (1995) Bax-deficient mice with lymphoid hyperplasia and male germ cell death. Science 270: $96-99$

15. Furuchi T, Masuko K, Nishimune Y, Obinata M and Matsui $Y$ (1996) Inhibition of testicular germ cell apoptosis and differentiation in mice misexpressing Bcl-2 in spermatogonia. Development 122: 1703-1709

16. Rodriguez I, Ody C, Araki K, Garcia I and Vassalli P (1997) An early and massive wave of germinal cell apoptosis is required for the development of functional spermatogenesis. EMBO J. 16: 2262-2270

17. Ross AJ, Waymire KG, Moss JE, Parlow AF, Skinner MK, Russell LD and MacGregor GR (1998) Testicular degeneration in Bcl-w-deficient mice. Nature Genetics 18: $251-256$

18. Print CG, Loveland KL, Gibson L, Meehan T, Stylianou A, Wreford N, de Kretser DM, Metcalf D, Kontgen F, Adams JM and Cory S (1998) Apoptosis regulator bcl-w is essential for spermatogenesis but appears otherwise redundant. Proc. Natl. Acad. Sci. USA 95: 12424-12431

19. Pritchard DM, Print CG, O'Reilly L, Adams JM, Potten CS and HickmanJA (2000) $\mathrm{Bcl}-\mathrm{w}$ is an important determinant of damage-induced apoptosis in epithelia of small and large intestine. Oncogene 19: 3955-3959

20. Dix DJ, Allen JW, Collins BW, Mori C, Nakamura N, Poorman-Allen P, Goulding EH and Eddy EM. (1996) Targeted gene disruption of Hsp70-2 results in failed meiosis, germ cell apoptosis, and male infertility. Proc. Natl. Acad. Sci. USA 93 3264-3268

21. MacGregor GR, Ross AJ, Richardson LL, Mahar PL, Waymire KG, Knudson CM Korsmeyer SJ, Thompson CB, Handel MA and Russell LD (1999) Analyisis of bcl2 family function in spermatogenesis. Goldberg $\mathrm{E}$, ed. In XVth Testis Workshop (Louisville, Kentucky: Serono Symposia USA Inc.) p. 55

22. Chomczynski Pand SacchiN (1987) Single-step method of RNA isolation by acid guanidinium thiocyanate-phenol-chloroform extraction. Anal. Biochem. 162: $156-159$
23. Meinhardt A, O'Bryan MK, McFarlane JR, Loveland KL, Mallidis C, Foulds LM Phillips DJ and de Kretser DM (1998) Localization of follistatin in the rat testis. J Reprod Fertil 112: 233-241

24. Yan W, Samson M, Jegou B and Toppari J (2000) Bcl-w forms complexes with $\mathrm{Bax}$ and Bak, and elevated ratios of $\mathrm{Bax} / \mathrm{Bcl}-\mathrm{w}$ and $\mathrm{Bak} / \mathrm{Bcl}-\mathrm{w}$ correspond to spermatogonial and spermatocyte apoptosis in the testis. Mol. Endocrinol. 14 $682-699$

25. Vilagrasa X, Mezquita C and Mezquita J (1997) Differential expression of bcl-2 and bcl-x during chicken spermatogenesis. Mol. Reprod. Dev. 47: 26-29

26. Yan W, Suominen J, Samson M, Jegou B and Toppari J (2000) Involvement of $\mathrm{Bcl}-2$ family proteins in germ cell apoptosis during testicular development in the rat and pro-survival effect of stem cell factor on germ cells in vitro. Mol. Cell. Endocrinol. 165: 115-129

27. Beumer TL, Roepers-Gajadien HL, Gademan IS, Lock TM, Kal HB and de Rooij DG (2000) Apoptosis regulation in the testis: involvement of Bcl-2 family members. Mol. Reprod. Dev. 56: 353-359

28. Krajewski S, Krajewski M, Shabaik A, Wang H-G, Irie S, Fong L and Reed JC (1994) Immunohistochemical analysis of in vivo patterns of Bcl-X expression. Canc. Res. 54: $5501-5507$

29. O'Reilly LA, Cullen L, Visvader J, Lindeman GJ, Print C, Bath ML, Huang DCS and Strasser A (2000) The pro-apoptotic BH3-only protein Bim is expressed in hematopoietic, epithelial, neuronal and germ cells. Am. J. Pathol. 157: 449-461

30. Eddy EM and O'Brien DA (1998) Gene expression during mammalian meiosis. Curr. Top. Dev. Biol. 37: 141-200

31. Wang RA, Nakane PK and Koji T (1998) Autonomous cell death of mouse male germ cells during fetal and postnatal period. Biol. Reprod. 58: 1250-1256

32. Hsu SY, Kaipia A, McGee E, Lomeli M and Hsueh AJ (1997) Bok is a proapoptotic $\mathrm{Bcl}-2$ protein with restricted expression in reproductive tissues and heterodimerizes with selective anti-apoptotic Bcl-2 family members. Proc. Natl. Acad. Sci. USA 94: 12401-12406

33. Inohara N, Gourley TS, Carrio R, Muniz M, Merino J, Garcia I, Koseki T, Hu Y, Chen S and Nunez G (1998) Diva, a Bcl-2 homologue that binds directly to Apaf-1 and induces BH3-independent cell death. J. Biol. Chem. 273: 32479-32486

34. Song Q, Kuang Y, Dixit VM and Vincenz C (1999) Boo, a novel negative regulator of cell death, interacts with Apaf-1. EMBO J. 18: 167-178

35. Loveland KL and Kretser DM (1999) Local Control of Spermatogenesis. Glover TD and Barratt CLR, eds. Male Fertility and Infertility. Cambridge University Press. pp. $56-84$

36. Olaso R, Pairault C, Boulogne B, Durand P and Habert R. (1998) Tranforming growth factor $\beta 1$ and $\beta 2$ reduce the number of gonocytes by increasing apoptosis. Endocrinology 139: 733-740

37. van Dissel-Emiliani FMF, de Boer-Brouwer M and de Rooij D. (1996) Effect of fibroblast growth factor-2 on Sertoli cells and gonocytes in coculture during the perinatal period. Endocrinology 137: 647-654

38. De Miguel MP, de Boer-Brouwer M, Paniagua R, van den Hurk R, De Rooij DG and Van Dissel-Emiliani FM. (1996) Leukemia inhibitory factor and ciliary neurotropic factor promote the survival of Sertoli cells and gonocytes in coculture system. Endocrinology 137: 1885-1893

39. Yan W, Suominen J and Toppari J. (2000) Stem cell factor protects germ cells from apoptosis in vitro. J. Cell Sci. 113: 161-168

40. Billig H, Furuta I, Rivier C, Tapanainen J, Parvinen M and Hsueh AJW. (1995) Apoptosis in testis germ cells: development changes in gonadotropin dependence and localisation to selective tubule stages. Endocrinology 136 : $5-12$

41. Lee J, Richburg JH, Shipp EB, Meistrich ML and Boekelheide K. (1999) The Fas system, a regulator of testicular germ cell apoptosis, is differentially upregulated in Sertoli versus germ cell injury of the testis. Endocrinology 140: 852-858

42. Huang DC, Hahne M, Schroeter M, Frei K, Fontana A, Villunger A, Newton K, Tschopp J and Strasser A (1999) Acitivation of Fas by FasL induces apoptosis by a mechanism that cannot be blocked by Bcl-2 or Bcl-x(L). Proc. Natl. Acad. Sci. USA 961: $14871-14876$ 